\title{
Stimulation of autotrophic denitrification by intrusions of the Bosporus Plume into the anoxic Black Sea
}

\section{Clara A. Fuchsman ${ }^{1}{ }^{*}$, James W. Murray ${ }^{1}$ and James T. Staley ${ }^{2}$}

1 School of Oceanography, University of Washington, Seattle, WA, USA

2 Department of Microbiology, University of Washington, Seattle, WA, USA

\section{Edited by:}

Bess B. Ward, Princeton University, USA

\section{Reviewed by:}

James T. Hollibaugh, University of Georgia, USA

Andreas Schramm, Aarhus University, Denmark

\section{*Correspondence}

Clara A. Fuchsman, School of

Oceanography, University of

Washington, Seattle, WA 98195-5351,

USA.

e-mail:cfuchsm1@u.washington.edu
Autotrophic denitrification was measured in the southwestern coastal Black Sea, where the Bosporus Plume injects oxidized chemical species (especially $\mathrm{O}_{2}$ and $\mathrm{NO}_{3}^{-}$) into the oxic, suboxic, and anoxic layers. Prominent oxygen intrusions caused an overlap of $\mathrm{NO}_{x}^{-}$ and sulfide at the same station where autotrophic denitrification activity was detected with incubation experiments. Several bacteria that have been proposed to oxidize sulfide in other low oxygen environments were found in the Black Sea including SUP05, Sulfurimonas, Arcobacter, and BS-GSO2. Comparison of TRFLP profiles from this mixing zone station and the Western Gyre (a station not affected by the Bosporus Plume) indicate the greatest relative abundance of Sulfurimonas and Arcobacter at the appropriate depths at the mixing zone station. The autotrophic gammaproteobacterium BS-GSO2 correlated with ammonium fluxes rather than with sulfide fluxes and the maximum in SUP05 peak height was shallower than the depths where autotrophic denitrification was detected. Notably, anammox activity was not detected at the mixing zone station, though low levels of DNA from the anammox bacteria Candidatus Scalindua were present. These results provide evidence for a modified ecosystem with different $\mathrm{N}_{2}$ production pathways in the southwest coastal region compared to that found in the rest of the Black Sea. Moreover, the same Sulfurimonas phylotype (BS139) was previously detected on $>30 \mu \mathrm{m}$ particles in the suboxic zone of the Western Gyre along with DNA of potential sulfate reducers, so it is possible that particle-attached autotrophic denitrification may be an overlooked $\mathrm{N}_{2}$ production pathway in the central Black Sea as well.

Keywords: Black Sea, autotrophic denitrification, Sulfurimonas, Bosporus Plume, anammox

\section{INTRODUCTION}

Three processes are responsible for $\mathrm{N}_{2}$ production under low oxygen conditions: (1) heterotrophic denitrification, which converts nitrate to $\mathrm{N}_{2}$ using organic matter as a reductant; (2) anammox, an autotrophic process which reduces nitrite with ammonium to form $\mathrm{N}_{2}$; and (3) autotrophic denitrification, which converts nitrate to $\mathrm{N}_{2}$ using reduced sulfur species as a reductant. In both heterotrophic and autotrophic denitrification, nitrate is reduced using the same pathway with $\mathrm{N}_{2} \mathrm{O}$ as an intermediate product (Sievert et al., 2008). Autotrophic denitrification has been found to be an important $\mathrm{N}_{2}$ production pathway in anoxic water columns in the Baltic Sea (Hannig et al., 2007), the Benguela upwelling zone (Lavik et al., 2009), and Mariager Fjord, Denmark (Jensen et al., 2009).

The Black Sea is a permanently anoxic basin with a welldefined redox gradient. A 20 - to 80 - $\mathrm{km}$ wide rim current circulates around the perimeter of the Black Sea, enclosing two cyclonic gyres (Poulain et al., 2005). In most of the Black Sea, the Cold Intermediate Layer, with a characteristic core density of $\sigma_{\theta} \approx 14.5$, represents the lower boundary of direct communication with the surface. The suboxic zone lies between the oxic Cold Intermediate Layer and a 2000-m thick sulfidic zone. In the central Black Sea, autotrophic denitrification is generally not thought to be important. Anammox has been detected in the suboxic zone (Kuypers et al., 2003; Jensen et al., 2008), and nitrate does not co-exist with sulfide or elemental S (Luther et al., 1991; Konovalov et al., 2003; Coban-Yildiz et al., 2006). However, the potential for $S$ cycling in suboxic waters without the build up of sulfide has recently been demonstrated in the Chilean Oxygen Minimum Zone (Canfield et al., 2010), and DNA from potential sulfate reducers and sulfide oxidizers were found attached to large particulate matter in the Black Sea suboxic zone (Fuchsman et al., 2011).

In the southwestern Black Sea, water from the bottom layer outflow of the Bosporus Strait mixes with the overlying Cold Intermediate Layer forming the Bosporus Plume (Buessler et al., 1991; Murray et al., 1991; Ivanov and Samodurov, 2001). This plume enters the Black Sea as thin intrusions into the oxic, suboxic, and sulfidic layers (Oguz and Rozman, 1991; Konovalov et al., 2003). These intrusions inject oxygen, nitrate, and other oxidized species into the anoxic layers, where they are reduced. The rim current transports water affected by the Bosporus Plume along the coast to the east (Basturk et al., 1999; Konovalov et al., 2003; Poulain et al., 2005). From ratios of ammonium and sulfide, Konovalov and Murray (2001) calculate that $1.11 \times 10^{12} \mathrm{~mol}$ of sulfide is missing from the Black Sea, and they attribute this loss to intrusions from the Bosporus Plume. They calculate that this approximates 
the re-oxidation of $50 \%$ of the sulfide production (Konovalov and Murray, 2001). Most of this sulfide oxidation is due to oxygen, but oxic intrusions also oxidize ammonium to nitrate/nitrite, which in turn can oxidize sulfide. Oxygen, nitrate, and nitrite intrusions were previously described at the mixing zone station in 2001 (Konovalov et al., 2003; Fuchsman et al., 2008). In this case, an intrusion of water from the Bosporus Plume created a second maximum in nitrate (up to $3.3 \mu \mathrm{M}$ ) at depths where sulfide is usually present (Fuchsman et al., 2008). The potential for autotrophic denitrification with sulfide is clearly present in the mixing zone of the Bosporus Plume in the Black Sea.

In this paper we provide evidence for autotrophic denitrification activity in the southwestern region of the Black Sea during an intrusion event of the Bosporus Plume, which caused overlap of $\mathrm{NO}_{\mathrm{x}}^{-}$and sulfide. We examine likely denitrifying bacteria by comparing depth profiles of normalized TRFLP peak height from the mixing zone with the western central gyre.

\section{MATERIALS AND METHODS SAMPLING}

Samples were collected using a CTD-Rosette with 10 L Niskin bottles and Sea-Bird sensors on three separate cruises in the Western Gyre of the Black Sea: (1) May 2001 at station 6 Voyage 162 leg 16 of the $R / V$ Knorr $\left(42^{\circ} 31^{\prime} \mathrm{N}, 30^{\circ} 43.5^{\prime} \mathrm{E}\right)$, (2) April 2003 at station 19 on Voyage 172 leg 7 of the R/V Knorr $\left(42^{\circ} 30^{\prime} \mathrm{N}, 31^{\circ} 00^{\prime} \mathrm{E}\right)$, and (3) late March 2005 at station 2 on cruise 403 of the $R / V$ Endeavor $\left(42^{\circ} 30^{\prime} \mathrm{N}, 30^{\circ} 45^{\prime} \mathrm{E}\right)$. Samples were also collected in the mixing zone where the Bosporus Plume enters the Black Sea (Figure 1) on two cruises: Station 20 in April $2003\left(41^{\circ} 26^{\prime} \mathrm{N}, 29^{\circ} 34^{\prime} \mathrm{E}\right)$ and Station 5 in March $2005\left(41^{\circ} 26^{\prime} \mathrm{N}, 2^{\circ} 34^{\prime} \mathrm{E}\right)$.

\section{NUTRIENT CONCENTRATIONS}

Oxygen was measured with the classic Winkler method, and sulfide by iodometric titration (Cline, 1969). In both cases, reagents were bubbled with argon to avoid contamination by atmospheric oxygen. Nitrate, nitrite, and ammonium were analyzed shipboard using a Technicon Autoanalyzer II system (see Fuchsman et al.,

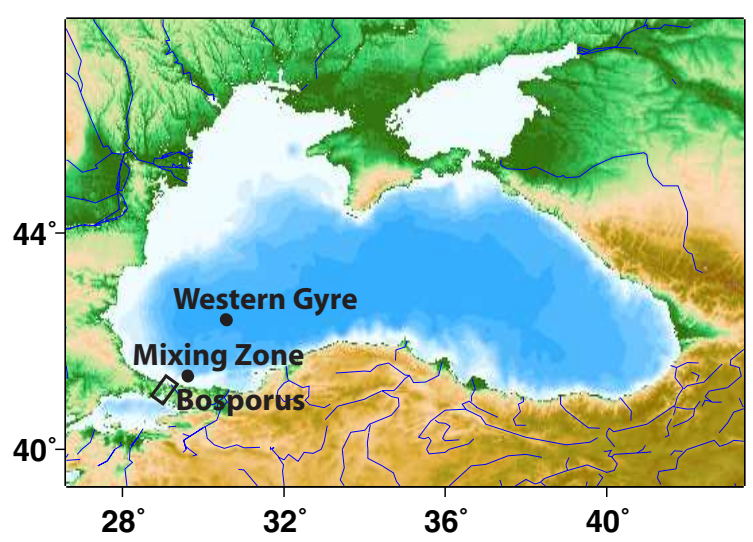

FIGURE 1 | A map of the Black Sea indicating the stations sampled in this study. This map was made with Map-It (http://woodshole.er.usgs. gov/mapit)
2008). Nitrate was not analyzed when there was consensus that sulfide would be in the sample.

\section{DNA}

For DNA samples, $2 \mathrm{~L}$ were filtered onto $0.2 \mu \mathrm{m}$ Millipore Sterivex filters. Samples were immediately frozen and stored at $-80^{\circ} \mathrm{C}$. The DNA extraction protocol was adapted from Vetriani et al. (2003) and includes $8-10$ freeze thaw cycles between a dry ice/ethanol bath and a $55^{\circ} \mathrm{C}$ water bath followed by chemical lysis with lysozyme and proteinase $\mathrm{K}$.

\section{TRFLP}

TRFLP profiles were obtained using universal bacterial primers 27F-FAM and 1517R (Vetriani et al., 2003). PCR products were amplified for 30 cycles with annealing temperature of $48^{\circ} \mathrm{C}$ using Fermentas PCR MasterMix. Purified PCR products (QiaQuick columns; Qiagen) were separately digested overnight with four restriction enzymes (HaeIII, Hpy1881, MspI, MnlI) and immediately ethanol precipitated (Fuchsman et al., 2011). TRFLP data from the Western Gyre in 2005 are previously published in Fuchsman et al. (2011).

Planctomycetes-specific TRFLP profiles were obtained using primers 58F-FAM and 926R (Wang et al., 2002). Planctomycetes PCR products were amplified for 30 cycles with annealing temperature of $60^{\circ} \mathrm{C}$. Purified PCR products (QiaQuick columns; Qiagen) were separately digested overnight with restriction enzymes HaeIII, Hpy 1881, and MspI and immediately ethanol precipitated (Fuchsman et al., 2012). Planctomycetes-specific TRFLP data for the Western Gyre in 2001, 2003, and 2005 are previously published in Fuchsman et al. (2012).

In both cases, analysis was performed on a MegaBACE 1000 apparatus (Molecular Dynamics) at the University of Washington Marine Molecular Biotechnology Laboratory. Electrophoretic profiles were visualized with Dax software (Van Mierlo Software Consultancy, Netherlands).

TRFLP profiles were normalized by total peak height. If the height of a peak was below $0.3 \%$ of the total peak height, the peak was removed from further statistical analyses. TRFLP peaks were binned using frame shifting (Hewson and Fuhrman, 2006) with four frames at $0.5 \mathrm{bp}$ intervals, and for each enzyme, a resemblance matrix was obtained using the Whitaker index, which takes abundance (peak height) into account (Fuchsman et al., 2011). The maximum similarity of the four frames was used to calculate the hierarchical cluster analysis (using the group average) with the Primer 6 program. Error in the resemblance matrix and significance level of the cluster diagram was determined using a Monte Carlo simulation of 50 replicates. We used the average error for both normalized peak height $[ \pm 46$ relative fluorescence units ( $\mathrm{rfu}$ ) where total peak height is $18,000 \mathrm{rfu}$ ] and base pairs $( \pm 0.08 \mathrm{bp})$ as determined by 16 sets of duplicate TRFLP profiles. The lowest similarity between Monte Carlo simulated replicates was $77 \%$ (Fuchsman et al., 2011). The average error for the Planctomycetes was $\pm 83 \mathrm{rfu}$, where total peak height was $15,000 \mathrm{rfu}$, and $\pm 0.06 \mathrm{bp}$ as determined by 14 sets of duplicate TRFLP profiles (Fuchsman et al., 2012).

Due to the replicability of the relative peak heights and the lack of cloning bias (Rainey et al., 1994), and because each PCR was 
run under the same conditions with similar extracts from the same amount of material, we were able to compare the relative abundance of the same restriction fragment (i.e., peak height) among multiple samples. However, due to PCR bias (Polz and Cavanaugh, 1998), comparison of heights among different restriction fragments was avoided. In other words, we only compare the relative abundance of a single taxon across samples and never compare the abundances of different taxa. More than one bacterial species can produce the same restriction fragment size; however, by ensuring that the shape of a fragment's relative abundance profile with depth must be supported by multiple enzymes, and by using a small bin size, that risk was reduced. Arguments supporting the similar use of fragment peak height in data from the Southern California time series station can be found in Steele et al. (2011).

Both TRFLP and pyrosequencing of the V6 region of $16 \mathrm{~S}$ rDNA were obtained from the Western Gyre in 2005 (Fuchsman et al., 2011). Both pyrosequencing and TRFLP avoid cloning biases (Rainey et al., 1994), but still contain PCR biases (Polz and Cavanaugh, 1998; Huse et al., 2008). Despite the use of different primers, conclusions from TRFLP data and V6 tag sequences compare well and we can identify many of the same OTUs using both techniques (Fuchsman et al., 2011). Not only are depth profiles of individual OTUs similar between techniques, but similarity indices are also similar when only V6 pyrosequences with $>1 \%$ relative abundance were used (Fuchsman et al., 2011).

Predicted fragment lengths for the phylotypes discussed here are shown in Table 1. TRFLP OTUs can represent a variety of taxonomic levels depending on the variability in the restriction sites among related phylotypes. Most of the TRFLP OTUs presented here represent a unique sequence or small group of very similar sequences. However, with the restriction enzymes used here Arcobacter clone BS098 (GU145483) has the same restriction sites as a wide range of Arcobacter members including Arcobacter nitrofigilis (L14627) and Black Sea sediment enrichment cultures (AJ271653-4) though they are not particularly closely related. In this paper, TRFLP OTUs are named after the phylotype that was present in the V6 pyrosequence data from the Western Gyre in 2005 (Fuchsman et al., 2011). Full length clones representing these phylotypes were amplified with TRFLP primers and digested with the restriction enzymes (Fuchsman et al., 2011). The actual length of digested clones often differ slightly from the lengths predicted in silico. Identifying TRFLP peaks with a database of digested clones greatly improves the reliability of peak identification. Unfortunately, we do not have a digested full length clone representing Arcobacter and the in silico prediction deviates slightly from the observed peaks (Table $\mathbf{1}$ ).

\section{AUTOTROPHIC DENITRIFICATION ACTIVITY EXPERIMENTS}

Samples for experiments were collected in 2005 at the mixing zone station at the shallowest depth where sulfide was detected $\left(\sigma_{\theta}=16.4 ; 192 \mathrm{~m}\right), 5 \mathrm{~m}$ below that depth $\left(\sigma_{\theta}=16.46 ; 197 \mathrm{~m}\right)$ and $20 \mathrm{~m}$ below $\left(\sigma_{\theta}=16.52 ; 212 \mathrm{~m}\right)$ as well as from a depth where no sulfide was detected $\left(\sigma_{\theta}=16.26 ; 178 \mathrm{~m}\right)$. Water was collected directly into $12.5 \mathrm{~mL}$ exetainers after overflowing with five times the volume of water. Vials were capped without the presence of bubbles. ${ }^{15} \mathrm{~N}$-labeled $\mathrm{NO}_{3}^{-}$was added (for final concentration of $27 \mu \mathrm{M})$ to duplicate samples from each depth. Samples and controls were incubated at $7^{\circ} \mathrm{C}$ for $48 \mathrm{~h}$. Experiments were stopped by addition of $\mathrm{HgCl}_{2}$, and $6 \mathrm{~mL}$ of water was replaced by helium and equilibrated overnight. Samples were measured directly by a Finnegan Delta XL isotope ratio mass spectrometer using the Conflo system in the Stable Isotope Lab, School of Oceanography, University of Washington. After gases were measured, the remaining water was analyzed for nitrite and ammonium concentrations using the Technicon Autoanalyzer II.

\section{RESULTS}

Due to the strong stratification of the Black Sea by salinity, characteristic inflections in the water-column profiles (such as nitrate) are generally associated with specific density values regardless of when and where they were sampled, but depths vary (Murray et al., 1995). Therefore, results presented here are plotted against

Table 1 | Taxonomy and predicted fragment lengths for the phylotypes discussed in this study.

\begin{tabular}{|c|c|c|c|c|c|c|c|}
\hline ID & Taxonomy & Accesssion & HaellI & Нру 1881 & Mspl & $M n / I$ & Primer \\
\hline JK200 & Scalindua & DO368308 & 236 & 530 & 259 & NA & 58F-926R \\
\hline BS142 & WS3 & GU145525 & 206 & - & 297 & 144 & $27 F-1512 R$ \\
\hline BS129 & BS-GSO2 & GU145512 & - & - & 165.3 & 139.2 & $27 F-1512 R$ \\
\hline BS098 & Arcobacter & GU145483 & 228 & - & S:474 & S:134 & $27 F-1512 R$ \\
\hline BS139 & Sulfurimonas & GU145522 & - & - & 465 & 130 & $27 \mathrm{~F}-1512 \mathrm{R}$ \\
\hline BS077 & SUP05 & GU145462 & 193 & - & 144.2 & 182.8 & 27F-1512R \\
\hline BS007 & SAR11 II & GU145392 & 292 & - & 147 & 121 & $27 F-1512 R$ \\
\hline BS110 & Marine group A & GU145495 & 227 & 290 & 450 & 286 & $27 \mathrm{~F}-1512 \mathrm{R}$ \\
\hline BSO40 & Cytophaga-like & GU145425 & 410 & - & 90 & - & $27 F-1512 R$ \\
\hline
\end{tabular}

$16 S$ rRNA clone PCR products were previously digested with all restriction enzymes and used to identify TRFLP peaks with a range \pm 0.5 bp from the length of the digested clone (Fuchsman et al., 2011) except for Arcobacter. Dashed line indicates that the enzyme did not cut the sequence within the size range examined (550 bp). NA stands for not applicable, $S$ for in silico, and T for in TRFLP profile. 
potential density $\left(\sigma_{\theta}\right)$ rather than depth $(\mathrm{m})$. Densities occurred up to $75 \mathrm{~m}$ deeper at the mixing zone station than at the Western Gyre station and varied up to $15 \mathrm{~m}$ between years at the Western Gyre (Figure A1 in Appendix).

\section{CHEMISTRY}

A station where the Bosporus Plume enters and mixes with the Black Sea was occupied in late April 2003 and in March 2005 (Figure 1). Oxygen, sulfide, and nutrient data from this mixing station are compared to data from the Western Gyre in Figures 2 and 3. In 2003, the Western Gyre and Mixing Zone stations had similar oxygen profiles above $\sigma_{\theta}=15.9$, but there was an intrusion of oxygen at $\sigma_{\theta}=16.15$ at the mixing zone. In 2003, sulfide was first detected at $\sigma_{\theta}=16.05(81 \mathrm{~m})$ in the Western Gyre, while in the mixing zone, sulfide became detectable above $\sigma_{\theta}=16.4$ (192 m; Figure 2). Nitrate maximum concentrations were similar between stations in 2003, and nitrite concentrations remained below $0.05 \mu \mathrm{M}$ (Figure 3). In 2005, the oxygen concentrations in the mixing zone station were greatly elevated. Oxygen was measured down to $\sigma_{\theta}=16.3(7 \mu \mathrm{M}, 180 \mathrm{~m}$; Figure 2$)$. Nitrate was $0.5 \mu \mathrm{M}$ at $\sigma_{\theta}=16.3$ while nitrite had a maximum of $0.18 \mu \mathrm{M}$ and was still elevated at $\sigma_{\theta}=16.4(192 \mathrm{~m}$; Figure 3). Sulfide was not detected at 16.3 on the two casts at this station but was $12 \mu \mathrm{M}$ just $6 \mathrm{~m}$ deeper on the cast not shown here. Given the detection limit for sulfide $(3 \mu \mathrm{M})$, it is possible that nitrate and sulfide overlapped at this station. In any case, the flux of sulfide to $\sigma_{\theta}=16.3$ was $303 \mu \mathrm{mol} \mathrm{m}^{-2} \mathrm{day}^{-1}$, so both nitrate and sulfide were available at this depth.

In the Western Gyre, oxygen extended deeper in the water column in 2005 than in other years. The top of the suboxic zone, defined as $<10 \mu \mathrm{M} \mathrm{O}_{2}$, was at $\sigma_{\theta}=15.38(72 \mathrm{~m})$ in 2001, $\sigma_{\theta}=15.6(61 \mathrm{~m})$ in 2003, and $\sigma_{\theta}=15.65(78 \mathrm{~m})$ in 2005. Higher oxygen concentrations at the Western Gyre in 2005 are due to a transitory lens of colder, more highly oxygenated water that appeared in the $\sigma_{\theta}=15.4-15.6$ range. On March 29th and 30th, the lens of more oxygenated water increased to $22 \mu \mathrm{M}$ oxygen at $\sigma_{\theta}=15.6$ and then decreased to $12 \mu \mathrm{M}$ at $\sigma_{\theta}=15.6$. When microbial samples were collected in 2001, oxygen concentrations (Figure 2) decreased from the top of the suboxic zone to near the detection limit at $\sigma_{\theta}=15.85$ and then increased to $2-4 \mu \mathrm{M}$ from $\sigma_{\theta}=15.92-16.05$.

Ammonium was consistently present in the lower suboxic zone at both stations and during all years. However ammonium fluxes at $\sigma_{\theta}=16.0$ (calculated with diffusion coefficients from Ivanov and Samodurov, 2001) varied between stations and years with the lowest fluxes $\left(190 \mu \mathrm{mol} \mathrm{m}^{-2} \mathrm{day}^{-1}\right)$ at the mixing zone station in 2003 and the western gyre in 2001 and the highest fluxes (330 and $310 \mu \mathrm{mol} \mathrm{m}^{-2} \mathrm{day}^{-1}$ ) from the mixing zone station in 2005 and from the western gyre in 2003. In 2005, the Western Gyre in 2005 had an intermediate flux $\left(270 \mu \mathrm{mol} \mathrm{m}^{-2}\right.$ day $\left.^{-1}\right)$.

\section{EVIDENCE FOR AUTOTROPHIC DENITRIFICATION}

In incubation experiments at the mixing zone station in 2005, where ${ }^{15} \mathrm{~N}$-labeled $\mathrm{NO}_{3}^{-}$was added, enriched $\delta^{30} \mathrm{~N}_{2}$, indicative of denitrification, was found in all sulfidic samples but $\delta^{30} \mathrm{~N}_{2}$ was not enriched in the non-sulfidic sample $\left[\sigma_{\theta}=16.26(178 \mathrm{~m}\right.$; Figure 4)]. The amount of enriched $\mathrm{N}_{2}$ increased with depth from an enrichment of $590 \%$ at $\sigma_{\theta}=16.4(192 \mathrm{~m})$ to an enrichment of $9800 \%$ at $\sigma_{\theta}=16.52(212 \mathrm{~m})$. In the ${ }^{15} \mathrm{~N}$-nitrate enriched samples from the sulfidic zone, there was substantial build up of nitrite, up to $18 \mu \mathrm{M}$ at $\sigma_{\theta}=16.46(197 \mathrm{~m}$; Figure 4) while ammonium concentrations were not different from controls.

Formation of $\delta^{29} \mathrm{~N}_{2}$ from ${ }^{15} \mathrm{~N}-\mathrm{NO}_{3}^{-}$enriched experiments is usually used to denote anammox activity. No enrichment in $\delta^{29} \mathrm{~N}_{2}$ was detected in the non-sulfidic sample $\left(\sigma_{\theta}=16.26\right)$, though ammonium was available from the ambient water, indicating that the anammox process was not occurring at that depth even though nitrite and ammonium were present. In the sulfidic zone, $\delta^{29} \mathrm{~N}_{2}$ was enriched by $1 \%$ o compared to controls. The relative abundance of Candidatus Scalindua, the genus of anammox bacteria in the Black Sea (Kirkpatrick et al., 2006), was low but present at $\sigma_{\theta}=16.4$ (Figure 3). However, the enrichment in $\delta^{29} \mathrm{~N}_{2}$ could also be from denitrification using small amounts of unspiked $\mathrm{NO}_{\mathrm{x}}^{-}$ or $\mathrm{N}_{2} \mathrm{O}$.
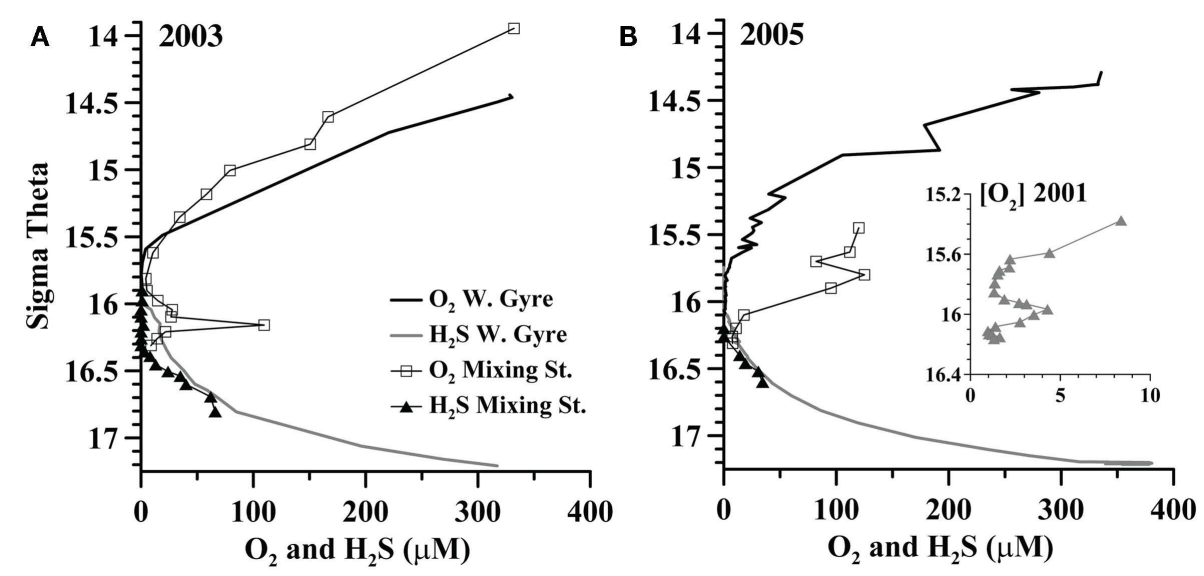

FIGURE 2 | A comparison between oxygen and sulfide in the Western Gyre and mixing zone stations in (A) 2003 and (B) 2005 . Inset: oxygen from the Western Gyre in 2001 during an intrusion event. 


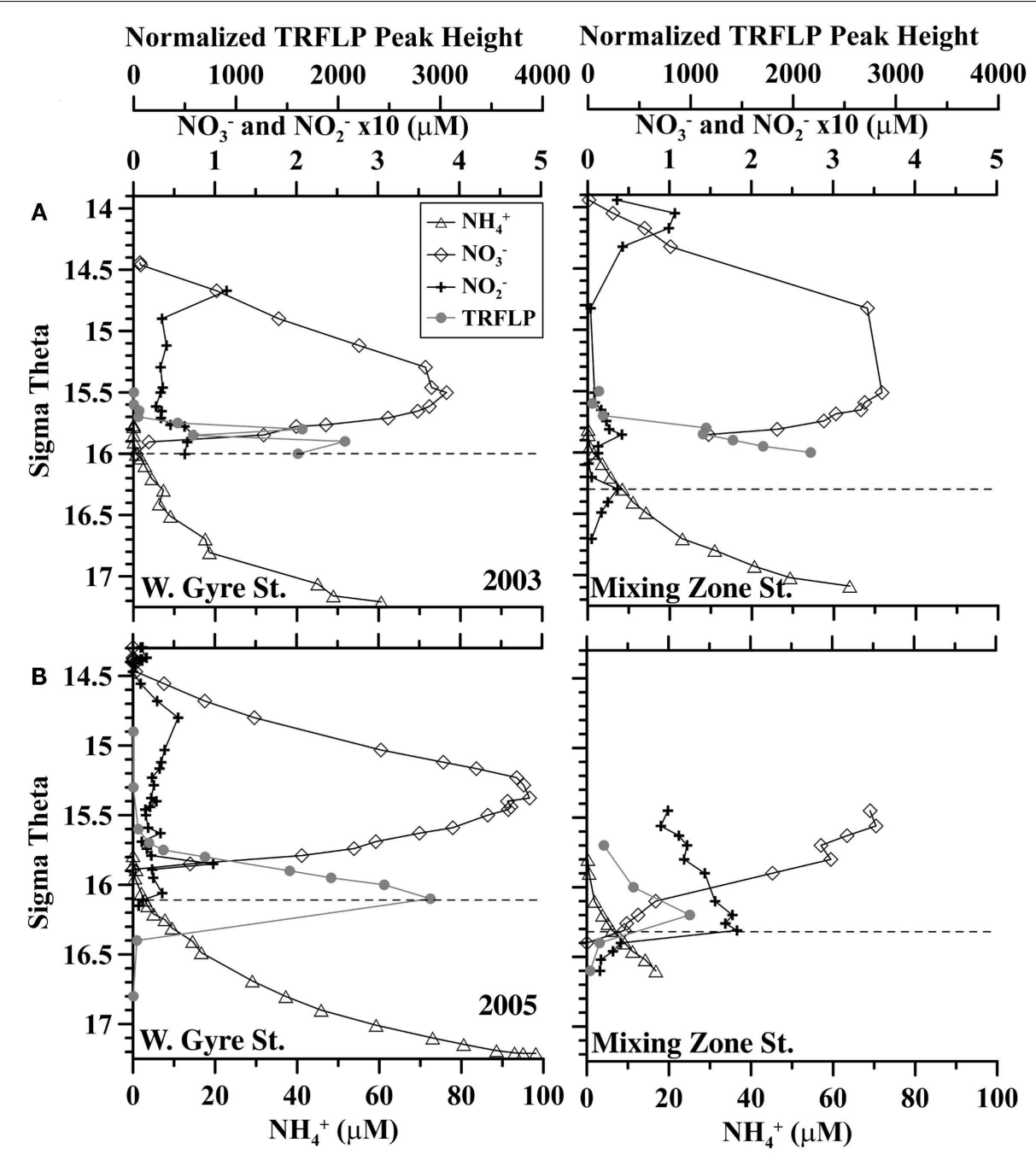

FIGURE 3 | Comparison of nitrate (diamonds), nitrite (crosses) ammonium (triangles), and Scalindua normalized TRFLP peak height (gray circles) between the Western Central Gyre and Mixing zone site in (A) 2003 and (B) 2005. Shallowest detection of sulfide is indicated by dashed lines. Average error in normalized peak height is \pm 83 rfu.

\section{BACTERIAL COMMUNITY}

A Spearman Rank correlation between environmental $\left(\left[\mathrm{O}_{2}\right]\right.$, $\left[\mathrm{H}_{2} \mathrm{~S}\right],\left[\mathrm{NO}_{3}^{-}\right],\left[\mathrm{NH}_{4}^{-}\right],\left[\mathrm{NO}_{2}^{-}\right],[\mathrm{PMn}]$ ) and biological (TRFLP) data indicated that a combination of nitrate, ammonium, and particulate manganese best explained all the bacterial data ( $R=0.698)$. Oxygen was not found to be a significant factor, likely because samples with 82 and $5 \mu \mathrm{M}$ oxygen have similar bacterial communities. However, if instead, the samples are binned into groups $>4 \mu \mathrm{M}$ oxygen, $<4 \mu \mathrm{M}$ oxygen, and sulfidic (see symbols in Figure 5), an ANOSIM analysis indicates that oxygen is a significant factor determining the differences in the bacterial communities $(R=0.460, p=0.001)$. In a pairwise test, the $>4 \mu \mathrm{M}$ oxygen and $<4 \mu \mathrm{M}$ oxygen communities were different $(R=0.316, p=0.001)$. The bacterial community does not seem to react linearly to oxygen, but instead to have a threshold.

The community at the mixing site and the central gyre were fundamentally similar. At some depths, the community at the mixing zone has $>60 \%$ similarity with the Whittaker index to communities at the western central gyre (Figure 5). However, there are some significant differences, especially in the sulfidic samples. We directly compared mixing zone station samples from 2005 to the same density at the central gyre station at two depths using the MspI, MnlI, and HaeIII restriction enzymes with a cutoff of $3 \%$ total peak height to reduce noise (Figure 6). At $\sigma_{\theta}=16.0$, a density surface which contained no oxygen in the Western Gyre $(97 \mathrm{~m})$ and $47 \mu \mathrm{M}$ oxygen at the mixing zone station in 2005 (166 m), the relative abundance of SAR11 clusters II phylotype BS007 was greater in the mixing zone station (Figure 6). The relative abundance of potential sulfur cycling bacteria Sulfurimonas phylotype BS139 and SUP05 BS077 phylotype along with unidentified MspI peak 498 was also greater at the mixing zone station. The HaeIII enzyme does not cut Sulfurimonas phylotypes, allowing Cytophaga phylotype BS040 to creep above the 3\% total peak height threshold for that enzyme. At $\sigma_{\theta}=16.4$, a density surface which is in the sulfate 


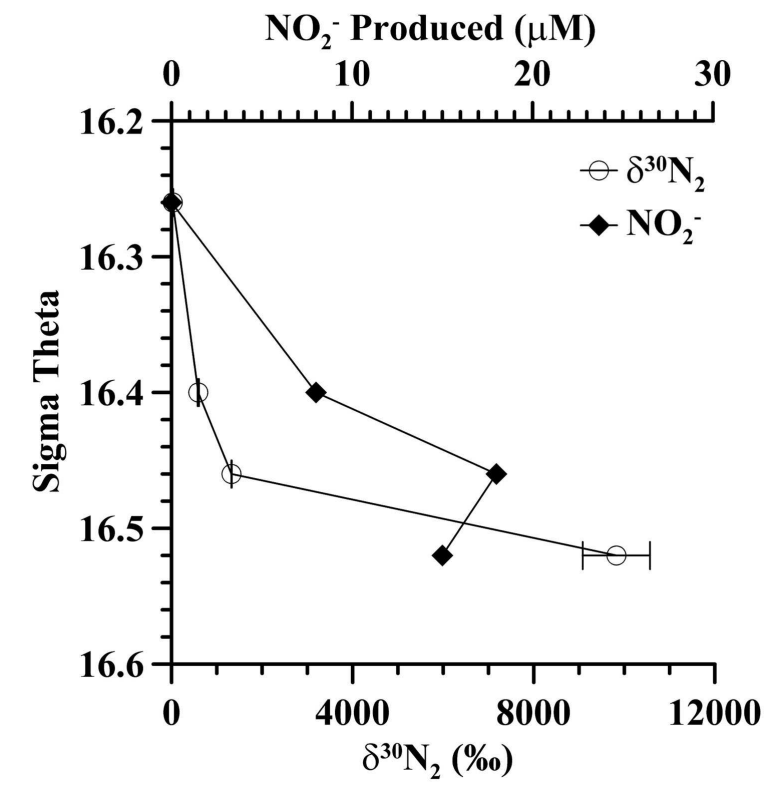

FIGURE 4 | Autotrophic denitrification activity at the mixing zone station in 2005 as indicated by ${ }^{30} \mathrm{~N}_{2}$ production (circles) during incubations with ${ }^{15} \mathrm{~N}$-labeled nitrate. Nitrite was also formed during the incubation (diamonds). Error bars indicate duplicate measurements.

reduction zone in the Western Gyre (141 m) but where autotrophic denitrification was detected at the mixing zone station (192 m), potential S oxidizers SUP05 BS077, Sulfurimonas BS139, Arcobacter BS098, and unidentified MspI peak 91/Mnl peak 254 pair had much higher normalized peak height in the mixing zone station compared to the Western Gyre (Figure 6). For the HaeIII enzyme, peak 206 representing the Black Sea WS3 group and unidentified peak 339 also had higher normalized peak height for the mixing station. The 206 cut site from HaeIII represents multiple WS3 phylotypes that are separate peaks when different restriction enzymes were used. Two WS3 phylotypes have been identified by TRFLP in the sulfidic zone of the Black Sea (Fuchsman et al., 2011, supplemental).

When we look at all profiles over five stations instead of just the two depths in 2005, we see that the relative abundances of BS139 from the Sulfurimonas genus of epsilonproteobacteria, BS077 from the SUP05 group of gammaproteobacteria, BS098 from the Arcobacter genus of epsilonproteobacteria, and unidentified MspI peak 91/Mnl peak 254 pair are clearly greater in the mixing zone station (Figures 7 and 8). Peaks 91/254 are in fact only seen in the mixing zone station in 2005 (Figure 8). Contrastingly, both group WS3 and peak 339 (HaeIII) have maxima in the sulfidic zone in the Western gyre (Figure 8), implying that their presence at the mixing zone station is not due to the intrusions there.

This dataset also allows us to examine variability in the bacterial community within the Western Gyre. Upper suboxic zone samples $\left(\sigma_{\theta}=15.5-15.7\right)$ from the Western Gyre in 2003 are included in the Suboxic cluster while upper suboxic zone samples from 2001 and 2005 are included in the Hypoxic cluster (Figure 5), perhaps due to the influence of oxygen intrusions in 2001 and 2005. In the deep suboxic zone, samples from 2001 clustered in a separate subcluster from samples from 2003 and 2005 (Figure 5). There was an oxygen intrusion into the deep suboxic zone in 2001 (Figure 2) and the particulate manganese maximum was also deeper. The maximum in particulate manganese at the Western Gyre varied $\sigma_{\theta}=16.05$ in 2001 (Konovalov et al., 2003) to $\sigma_{\theta}=15.8-15.85$ in 2003 and 2005 (Trowborst et al., 2006; Fuchsman et al., 2011).

\section{PLANCTOMYCETES COMMUNITY}

The members of the Planctomycetes community at the mixing station were similar to those described in Fuchsman et al. (2012) with $60-70 \%$ community similarity to samples from the Western Gyre. MspI peak 263, representing WS3 bacteria, had high peak height in the sulfidic mixing zone samples from 2005, corroborating information from the bacterial primers. At the mixing zone station, Scalindua peak height increased with depth starting at $\sigma_{\theta}=15.7$ in 2003, while in 2005 Scalindua peak height had a maximum at $\sigma_{\theta}=16.2$ (Figure 3). At $\sigma_{\theta}=16.0$, in the mixing zone station, Scalindua normalized peak height was significantly lower in 2005 than in 2003 (Figure 3).

The chemical parameters that most strongly correlated with the Planctomycetes community similarity among samples (Spearman Rank correlation) were nitrate, ammonium, and sulfide ( $R=0.730$ when combined), but ammonium and nitrate without sulfide explained most of the data $(R=0.729)$. Oxygen concentration was not found to be an important variable. However, the bacterial communities generally cluster by the presence of $>3$ or $<3 \mu \mathrm{M}$ oxygen or sulfide (ANOSIM $R=0.386, p=0.001$ ) supporting the importance of an oxygen threshold.

\section{DISCUSSION}

In the southwestern coastal Black Sea, intrusions from the Bosporus Plume inject oxygen, nitrate, and other oxidized species into the sulfidic layer (Konovalov et al., 2003). In 2005, there was abundant evidence of intrusions at the mixing zone station. Oxygen, usually only measurable to around $\sigma_{\theta}=15.8$, was measured down to $\sigma_{\theta}=16.3$ (Figure 2). Nitrate and nitrite were also unusually elevated at $\sigma_{\theta}=16.3$ and nitrite concentrations were still elevated at $\sigma_{\theta}=16.4$ (Figure 3). Sulfide was not detected at 16.3 (detection limit $3 \mu \mathrm{M}$ ), but the flux of sulfide to $\sigma_{\theta}=16.3$ was $303 \mu \mathrm{mol} \mathrm{m}^{-2} \mathrm{day}^{-1}$, so both nitrate and sulfide were available. In experiments at the mixing zone station in 2005, where ${ }^{15} \mathrm{~N}$-labeled $\mathrm{NO}_{3}^{-}$was added, enriched $8^{30} \mathrm{~N}_{2}$ was found in all sulfidic samples but not in the non-sulfidic sample $\left(\sigma_{\theta}=16.26\right.$; Figure 4). This implies autotrophic denitrification activity with sulfide as an electron donor. If we convert these enrichments to experimental rates, they range from $4 \mathrm{nM} \mathrm{N} \mathrm{day}^{-1}$ at $\sigma_{\theta}=16.4$ to $10 \mathrm{nMN} \mathrm{day}^{-1}$ at $\sigma_{\theta}=16.46$ and $78 \mathrm{nMN} \mathrm{day}^{-1}$ at $\sigma_{\theta}=16.52$. These rates are an order of magnitude lower than experiments with comparable nitrate concentrations in Mariager Fjord (Jensen et al., 2009). These experimental rates do not represent in situ rates because nitrate additions $(27 \mu \mathrm{M})$ were much higher than the largest values seen in situ ( $\sim 3 \mu \mathrm{M}$; Fuchsman et al., 2008). Additionally, the positive dependence of autotrophic denitrification on sulfide concentration and the large accumulation of nitrite in the experiments $(18 \mu \mathrm{M})$ are both consistent with trends seen 


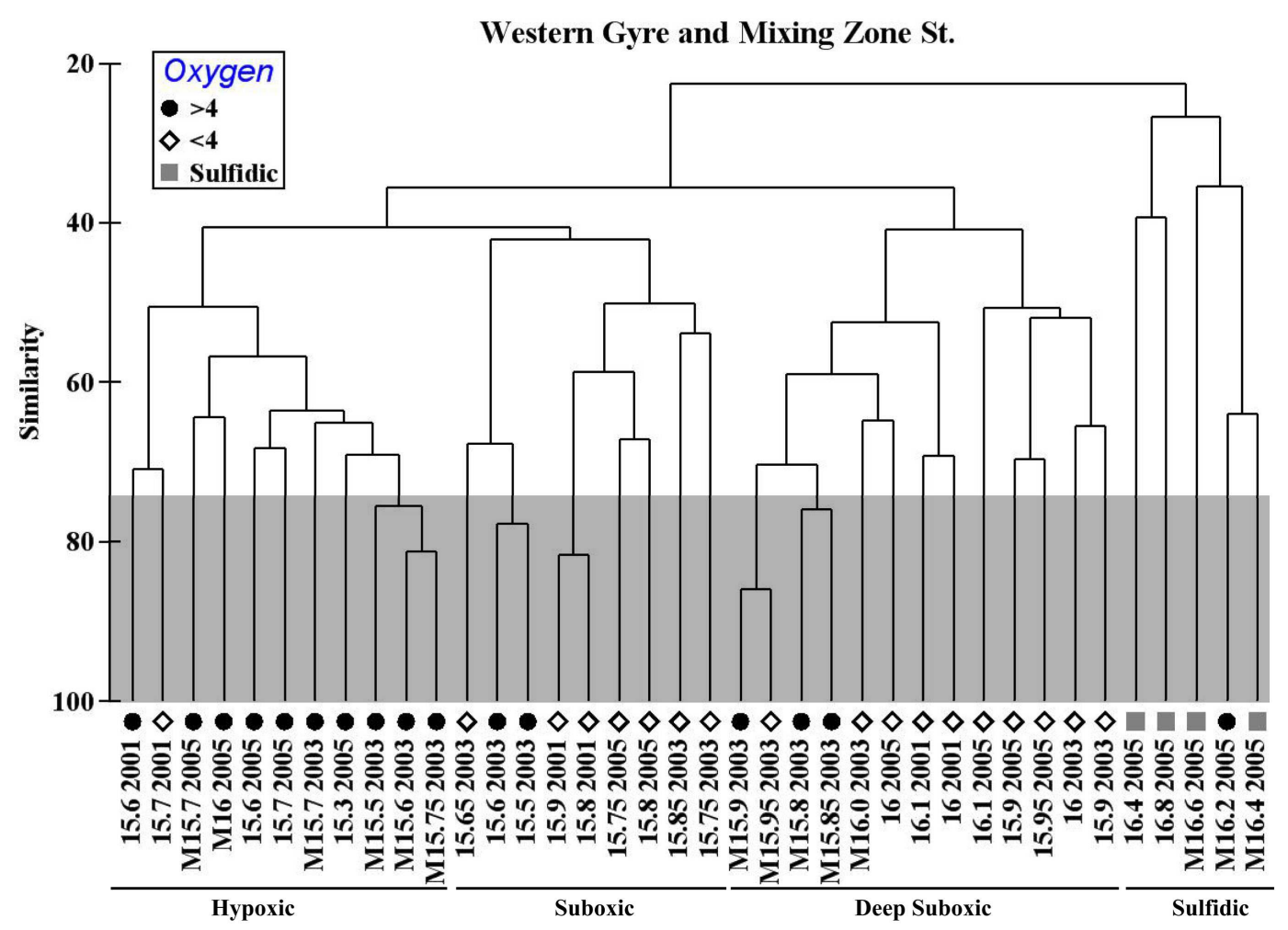

FIGURE 5 | Hierarchical cluster of the bacterial community as determined by TRFLP data (Mspl) from Western Gyre in 2001, 2003, and 2005 and Mixing Zone Site in $\mathbf{2 0 0 3}$ and 2005. Samples are named by the sigma theta and year where they were obtained. $M$ indicates mixing zone station.
Symbols indicate oxygen concentrations: $>4 \mu \mathrm{M} \mathrm{O}_{2}$ (circle), $<4 \mu \mathrm{M} \mathrm{O}_{2}$ (diamond), sulfidic (square). Error was determined using a Monte Carlo simulation; nodes within the gray box are not significantly different (e.g., $\sigma_{\theta}=15.5-15.75$ from the 2003 mixing zone site). in Mariager Fjord, Denmark (Jensen et al., 2009) and may be due to sulfide limitation. The accumulation of nitrite could also be due to the slower kinetics of nitrite reduction compared to nitrate reduction (Jensen et al., 2009) or to bacteria that merely perform the first step of nitrate reduction (Zumft, 1997). However, the consumption of five moles of sulfide for every two moles of nitrate (Jensen et al., 2009) indicates that sulfide limitation was likely in all of the experiments, but would have been especially important in the $\sigma_{\theta}=16.4$ experiment $\left(14 \mu \mathrm{M} \mathrm{H} \mathrm{H}_{2} \mathrm{~S}\right)$. While not indicating in situ rates, these experiments do indicate the ability of the bacterial community in the sulfidic zone of the mixing station to reduce nitrate when it becomes available, likely through intrusions from the Bosporus Plume.

Though the highest denitrification activity was seen at $\sigma_{\theta}=16.52$ with the addition of nitrate (Figure 4), it seems more likely that in situ rates at the time of sampling were higher between $\sigma_{\theta}=16.3$ and 16.4 where in situ nitrate/nitrite were naturally present (Figure 3 ). We also have DNA samples from $\sigma_{\theta}=16.4$. The relative abundances of BS139 from the Sulfurimonas genus of epsilonproteobacteria, BS077 from the SUP05 group of gammaproteobacteria, BS098 from the Arcobacter genus of epsilonproteobacteria, and unidentified MspI peak 91/Mnl peak 254 pair are all clearly greater at $\sigma_{\theta}=16.4$ of the mixing zone station in 2005 compared to the Western Gyre (Figure 6). Members of the Candidatus genus Scalindua, known to mediate the anammox reaction but typically missed by universal bacterial primers, were also present at $\sigma_{\theta}=16.4$ at the mixing zone. Additionally, a labeled bicarbonate stable isotope probing experiment at the chemosynthesis maximum in the upper sulfidic zone of the central Black Sea in 2007, attributed autotrophic activity not only to members of the genus Sulfurimonas and the SUP05 (Glaubitz et al., 2010), found to be enriched in the mixing zone station in this study, but also to members of the BS-GSO2 group of gammaproteobacteria (Glaubitz et al., 2010). In the following section we examine these six bacteria to determine which was the most likely to mediate $\mathrm{N}_{2}$ production in the mixing zone site in 2005.

\section{ANAMMOX}

Sequences of potential anammox bacteria in the Black Sea are of the Candidatus Scalindua genus (Kirkpatrick et al., 2006). In the mixing zone station in 2005, Scalindua peak height had a maximum at $\sigma_{\theta}=16.2$ (Figure 3). This maximum was much reduced from the maximum at the same station in 2003 and from the Western Gyre in 2005 (Figure 3). Anammox activity was not detected at the mixing zone station in 2005 , though only one depth was examined. However, that depth did correspond to the maximum in Scalindua peak height. Scalindua DNA at the mixing zone station may be remnants from previous activity, or Scalindua may be mediating Fe or Mn oxide reduction (van de Vossenberg et al., 2008). 

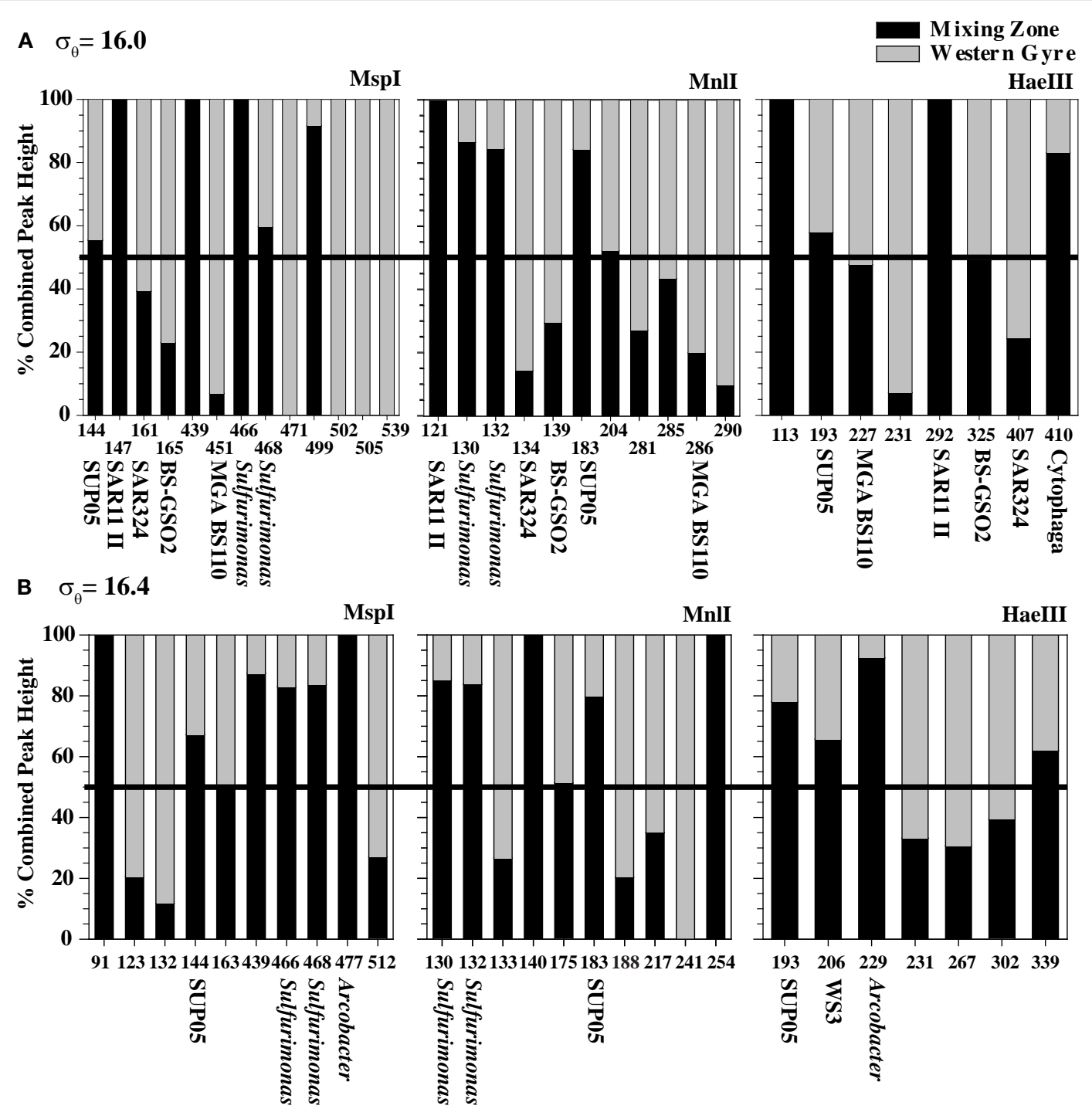

FIGURE 6 |A comparison of TRFLP chromatograms from (A) $\sigma_{\theta}=16.0$ and (B) $\sigma_{\theta}=16.4$ for three restriction enzymes at the Mixing Zone Station (black) and the Western Gyre (gray) where the $x$-axis displays different TRFLP peaks and the $y$-axis is the percent of peak height associated with each chromatogram. The black line at 50\% indicates where the relative peak height is the same at each station. Only peaks with normalized peak height above $3 \%$ of the total peak height are shown.

\section{SUP05}

A metagenome of SUP05 bacteria from Saanich Inlet, a seasonally anoxic fjord on Vancouver Island, Canada indicated that the SUP05 group of gammaproteobacteria had the ability to autotrophically oxidize sulfur compounds and also contain genes for the production of $\mathrm{N}_{2} \mathrm{O}$ (Walsh et al., 2009). Subsequently, SUP05 phylotypes were shown to be autotrophic in the upper sulfidic zone of the central Black Sea (Glaubitz et al., 2010). Transcripts of sulfur oxidizing genes from the SUP05 group have also been detected in the Chilean Oxygen Minimum Zone (Stewart et al., 2012). Altogether, this evidence could suggest a potential for autotrophic denitrification. Normalized TRFLP peak height for BS077 (the dominant SUP05 phylotype in the Black Sea) was much greater in the mixing zone stations than in the Western Central Gyre stations. However, phylotype BS077 had a maximum peak height at $\sigma_{\theta}=16.2$ in the 2005 mixing zone station, which was shallower than the depths where autotrophic denitrification was detected (Figure 7).

\section{BS-GS02}

A second group of uncultured gammaproteobacteria, BS-GSO2, was implicated in autotrophic activity in the upper sulfidic zone of both the Black and the Baltic Seas (Glaubitz et al., 2009, 2010) and linked to autotrophic denitrification in the Benguela upwelling zone (Lavik et al., 2009). Autotrophic activity in these sulfidic zones implies this group might be involved in sulfur oxidation (Glaubitz et al., 2009, 2010). BS129 (the dominant BS-GSO2 phylotype in the Black Sea) was identified in all years and stations but its relative abundance was greater in the Western Gyre than in the mixing zone station in 2005 (Figure 8). At the mixing station in 2005, BS129 

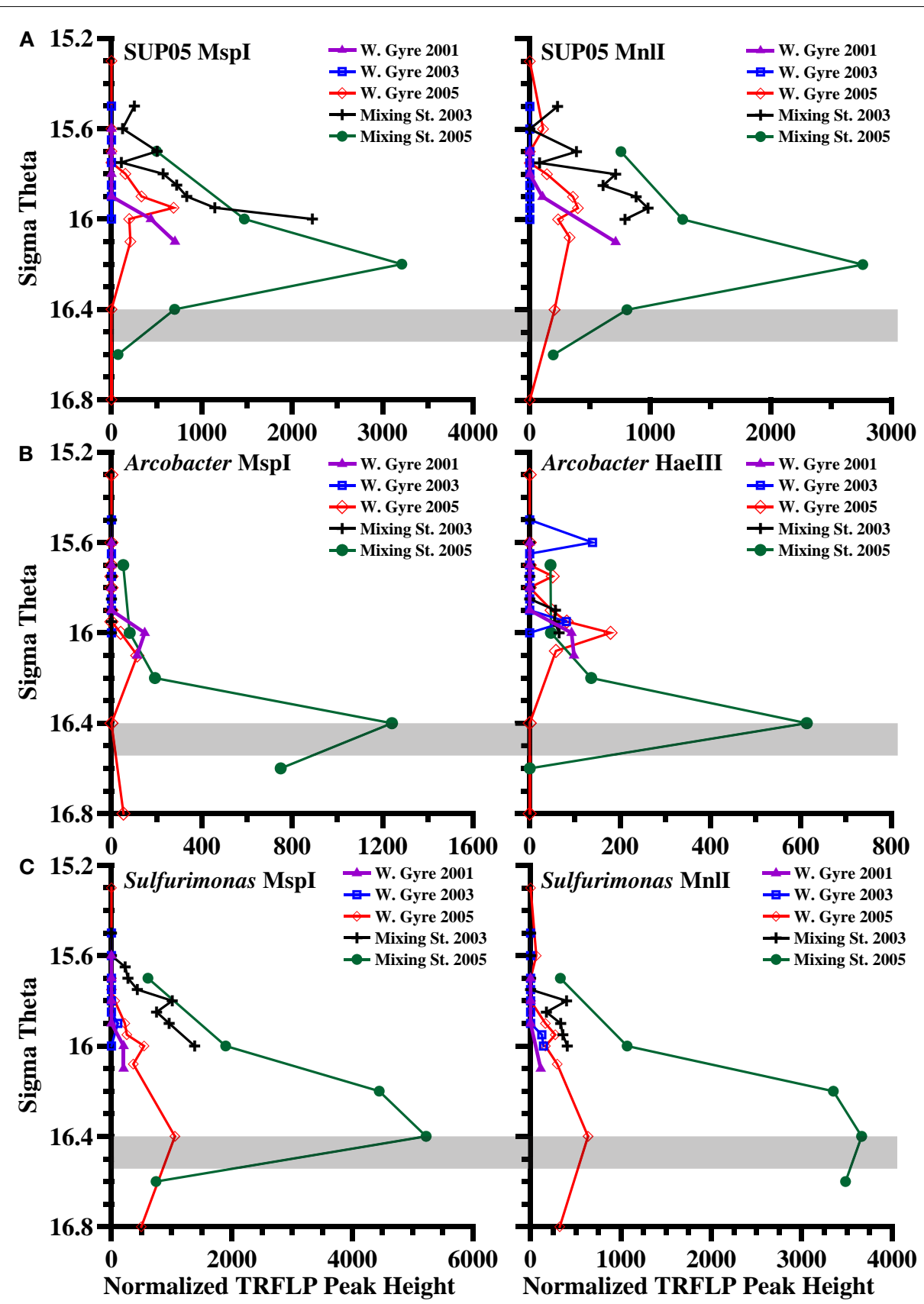

FIGURE 7 |TRFLP peak height depth profiles of autotrophic denitrification candidates that are enriched at the mixing zone station in 2005, obtained using multiple restriction enzymes, for the five stations: (A) Black Sea SUP05 phylotype BS077, (B)
Arcobacter phylotype BS098, (C) Black Sea Sulfurimonas phylotype BS139. The gray box indicates the range of autotrophic denitrification activity seen in the Mixing Zone station in 2005 (Figure 4). had a maximum peak height at $\sigma_{\theta}=16.2$, and its relative peak height was greatly reduced at $\sigma_{\theta}=16.4$, where autotrophic denitrification activity was detected (Figure 8). In fact, the normalized peak height for BS129 at $\sigma_{\theta}=16.0$ appears to be anti-correlated with ammonium flux (Figure 8; $p=0.004$ for MspI). Normalized TRFLP peak height was greatest at the mixing zone station in 2003 and the Western Gyre in 2001 where ammonium fluxes were lowest. BS129 peak height was lowest in the Western Gyre in
2003 and the mixing zone station in 2005, both of which had high ammonium fluxes. Interestingly, an unknown gammaproteobacterium was found to mediate ammonium oxidation in the lower suboxic zone (Lam et al., 2007). Therefore, considering its correlation with ammonium fluxes, depth profile (Figure 8), and ability to fix carbon (Glaubitz et al., 2010), BS129 seems a likely candidate for autotrophic ammonium oxidation, but not autotrophic denitrification. 

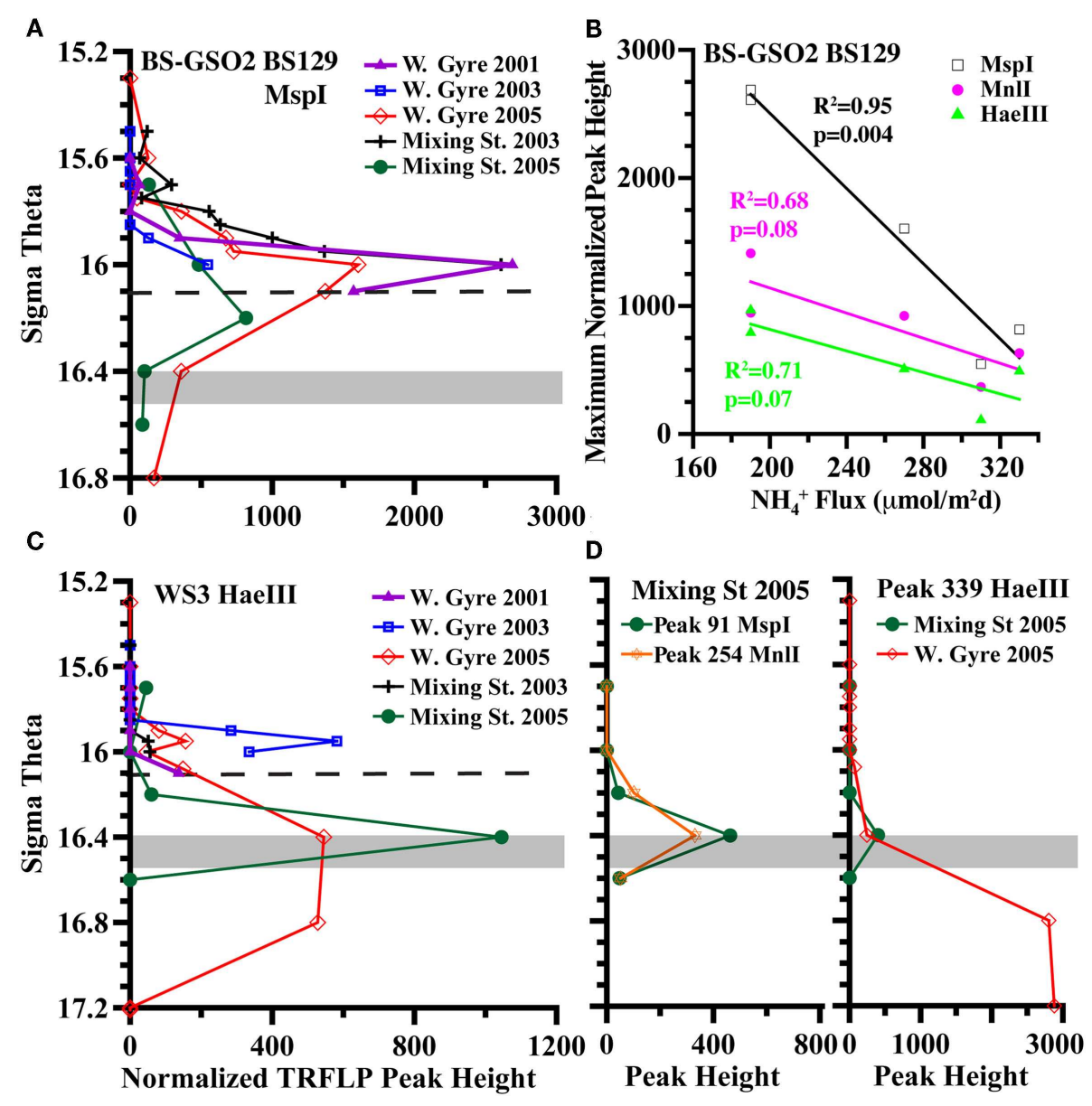

FIGURE 8 | Examination of autotrophic denitrification candidates (A) TRFLP peak height depth profiles of BS-GSO2 phylotype BS129, (B) the inverse correlation of BS129 peak height with ammonium fluxes at $\sigma_{\theta}=\mathbf{1 6 . 0}$ at all five stations with a comparison between restriction enzymes, (C) TRFLP peak height depth profiles of WS3, and (D) depth profiles of unidentified peak 91 from digestion with $\mathbf{M s p l}$ and peak 254 from digestion with $\mathbf{M n I l}$ and peak 339 from digestion with Haelll. Dashed line indicates a typical depth for the shallowest detection of sulfide in the Western Gyre. The gray box indicates the range of autotrophic denitrification activity seen in the Mixing Zone station in 2005 (Figure 4).

\section{ARCOBACTER}

In the Benguela upwelling zone the epsilonproteobacteria Arcobacter were found at depths where autotrophic denitrification occurred (Lavik et al., 2009). Arcobacter sulfidicus has been found to autotrophically oxidize sulfide with oxygen forming elemental S mats (Wirsen et al., 2002; Sievert et al., 2007). Arcobacter phylotypes have been associated with such mats at sulfidic/oxic boundaries at hydrothermal vents, cold seeps, and the sediment water interface (Taylor and Wirsen, 1997; Moussard et al., 2006; Grunke et al., 2011). The Arcobacter depth profile in the Black Sea (Figure 7) would be consistent with either autotrophic denitrification or microaerophilic sulfide oxidation. The cultured representative, A. sulfidicus, which is closely related to BS098 found in the Black Sea (Figure 9), is microaerophilic and is incapable of oxidizing sulfide with nitrate (Wirsen et al., 2002). Some Arcobacter species can reduce nitrate heterotrophically (Heylen et al., 2006) but these isolates are not closely related to BS098 (Figure 9). Other Arcobacter enrichment cultures from sediments, such as Black Sea sediments (Thamdrup et al., 2000), have been found to reduce manganese oxides with acetate (Vandieken et al., 2012). The maximum in particulate manganese at the mixing zone station in 2005 is at $\sigma_{\theta}=16.3$ (B. Tebo, personal communication). The versatility of the Arcobacter genus makes predictions of the activity of the species at the mixing zone station particularly difficult.

\section{SULFURIMONAS}

Members of the Sulfurimonas genus of Epsilonproteobacteria have been associated with autotrophic denitrification in the marine environment; many known strains of Sulfurimonas from hydrothermal vents and marine sediments can carry out autotrophic denitrification (Gevertz et al., 2000; Takai et al., 2006), and environmental clones affiliated with the genus have been extracted from marine sediments and correlated with active autotrophic denitrification (Shao et al., 2009; Zhang et al., 2009). Sulfurimonas phylotype GD17 has been found to mediate autotrophic denitrification in the Baltic Sea (Brettar et al., 2006). Black Sea sequences are closely related to GD17 from the Baltic Sea as well as to Sulfurimonas denitrificans (Glaubitz et al., 2010; 


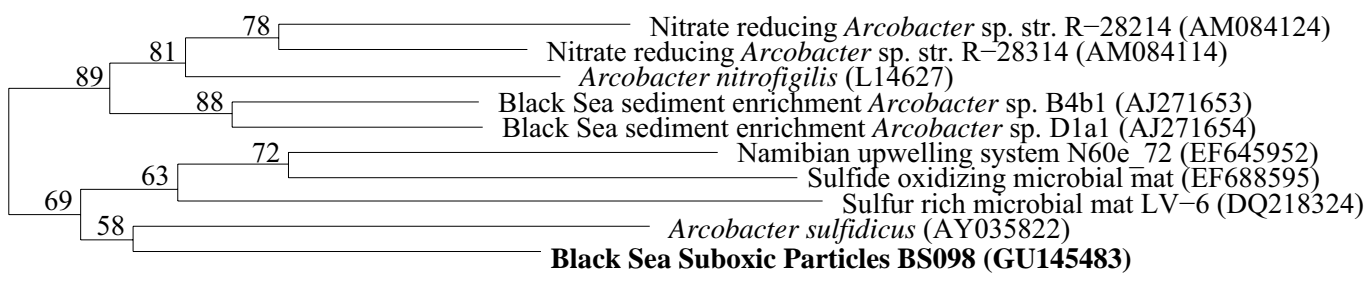

0.10

FIGURE 9 |A bootstrapped (1000) neighbor joining phylogenetic tree of relevant members of the Arcobacter genus was created in arb after aligning to a master database using NAST (greengenes.lbl.gov). The Arcobacter sequence from the Black Sea suboxic zone is in bold.

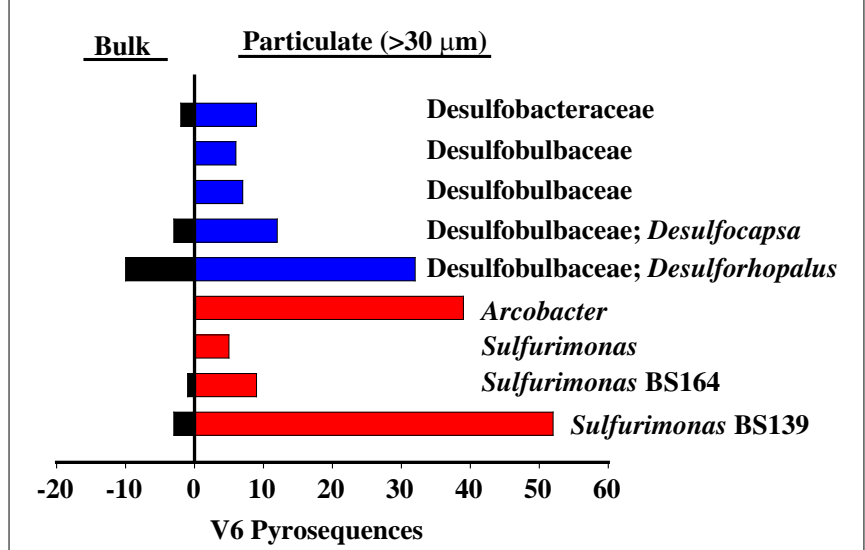

FIGURE 10 | Examples of potential sulfate reducers (blue) or sulfide oxidizers (red) enriched in particulate sample ( $30 \mu \mathrm{m}$ filter) from $\sigma_{\theta}=15.8$ in the Western Gyre in 2005 compared to a bulk sample from the same depth, as determined from V6 pyrosequences (data from Fuchsman et al., 2011, supplemental).

Fuchsman et al., 2011). The normalized TRFLP peak height of Sulfurimonas phylotype BS139 was up to 10 times greater in the mixing zone stations than in the Western Central Gyre stations (Figure 7). The phylotype BS139 had a maximum peak height from $\sigma_{\theta}=16.2-16.4$ in the 2005 mixing zone station and still had significant abundance at $\sigma_{\theta}=16.6$ (Figure 7). Thus the Sulfurimonas peak spanned the depths where autotrophic denitrification activity was detected (Figure 4 ) and remains the leading candidate for mediating autotrophic denitrification.

Sulfurimonas was also enriched at $\sigma_{\theta}=16.2$. The presence of Sulfurimonas DNA at the Western Gyre site in 2005, 2007, and 1988 (Vetriani et al., 2003; Glaubitz et al., 2010) also implies Sulfurimonas can live at depths where sulfide is not detectable. There are two possible explanations for this. First, the depth profile for thiosulfate, another potential electron source for autotrophic bacteria (Takai et al., 2006) is unknown in the Black Sea during this time period. Second, pyrosequences of the V6 variable region of $16 \mathrm{~S}$ rRNA identical to Sulfurimonas phylotype BS139 were also present in the particulate fraction in the suboxic zone in Western Gyre of the Black Sea, along with a Desulfobacter phylotype BS105 (GU145490) and pyrosequences from potential sulfate reducers from the Desulfobulbaceae and Desulfuromonadales families (Figure 10; data from Fuchsman et al., 2011). Many but not all cultured members of these families are sulfate reducers (e.g., Finster et al., 1994; Hoeft et al., 2004; Tarpgaard et al., 2006; Vandieken et al., 2006). Arcobacter V6 pyrosequences were also found on the particulate material and BS098 was sequenced from the particulates (Fuchsman et al., 2011). If Sulfurimonas phylotype BS139 or Arcobacter phylotype BS098 are indeed responsible for autotrophic denitrification in the mixing zone station, their presence on large particles in the nitrate-rich suboxic zone of the Western Gyre indicates that autotrophic denitrification may be fed by sulfate reduction inside sinking aggregates. This form of denitrification could easily have been missed in experiments by Jensen et al. (2008) due to the patchy nature of sinking particulate matter and the hydrodynamics of Niskin bottles (Altabet et al., 1992).

\section{CONCLUSION}

Chemical profiles indicate that nitrate and sulfide may have coexisted at the mixing zone station in 2005 (Figures 2 and 3 ). ${ }^{15} \mathrm{~N}-\mathrm{NO}_{3}^{-}$tracer experiments indicate autotrophic denitrification occurred in the sulfidic zone at this station (Figure 4). Though SUP05 and BS-GSO2 bacteria are autotrophic and have been found in sulfidic environments (Glaubitz et al., 2009, 2010; Lavik et al., 2009; Walsh et al., 2009), their depth profiles are not consistent with autotrophic denitrification at this station. Instead the depth profile for BS-GSO2 phylotype BS129 correlated with ammonium fluxes. In contrast, Sulfurimonas BS139, Arcobacter BS098, and unidentified MspI peak 91/Mnl peak 254 pair have their greatest relative abundance in the zone where autotrophic denitrification was detected (Figure 7). Out of these three bacteria, we consider the Black Sea Sulfurimonas to be the most likely candidate for this denitrification because many Sulfurimonas species have previously been found to mediate autotrophic denitrification (Gevertz et al., 2000; Brettar et al., 2006; Takai et al., 2006). Evidence for the involvement of Arcobacter and peak 91 is less clear.

For most of the Black Sea, both anammox (Kuypers et al., 2003; Jensen et al., 2008) and heterotrophic denitrification (Fuchsman et al., 2008) are the important nitrogen loss pathways. Biogeochemical modeling indicates that autotrophic denitrification from overlapping depth profiles of nitrate and sulfide may only contribute $1 \%$ to nitrogen loss in the central Black Sea (Konovalov et al., 2008). However, where the Bosporus enters the Black Sea, 
autotrophic denitrification appears to be more important, and autotrophic denitrification associated with sinking particles has not yet been quantified. Future work should investigate these possibilities in order to better constrain the role of autotrophic denitrification in the Black Sea's nitrogen cycle.

\section{ACKNOWLEDGMENTS}

We would like to thank Barbara Paul for collecting DNA samples from 2001. We would like to thank S. Tugrul, T. Uysal,

\section{REFERENCES}

Altabet, M. A., Bishop, J. K. B., and McCarthy, J. J. (1992). Differences in particulate nitrogen concentration and isotopic composition for samples collected by bottles and large-volume pumps in gulfstream warm-core rings and the Sargasso Sea. Deep Sea Res. A 39, S405-S417.

Basturk, O., Yakushev, E. V., Tugrul, S., Salihoglu, I. (1999) "Characteristic chemical features and biogeochemical cycles in the Black Sea," in Environmental Degradation of the Black Sea: Challenges and Remedies, eds S. Besiktepe, U. Unluata, and A. Bologa (Dordrecht: Kluwer Academic Publishers), 43-59.

Brettar, I., Labrenz, M., Flavier, S., Botel, J., Christen, R., and Hofte, M. G. (2006). Identification of a Thiomicrospira denitrificans like epsilon proteobacteria as a catalyst for autotrophic denitrification in the central Baltic Sea. Appl. Environ. Microbiol. 72, 1364-1372.

Buessler, K. O., Livingston, H. D., and Casso, S. A. (1991). Mixing between oxic and anoxic waters of the Black Sea as traced by Chernobyl cesium isotopes. Deep Sea Res. A 38, S725S746.

Canfield, D. E., Stewart, F. J., Thamdrup, B., De Brabandere, L., Dalsgaard, T., Delong, E. F., Revsbech, N. P., and Ulloa, O. (2010). A cryptic sulfur cycle in oxygen-minimumzone waters off the Chilean coast. Science 330, 1375-1378.

Cline, J. D. (1969). Spectrophotometric determination of hydrogen sulfide in natural waters. Limnol. Oceanogr. 14, 454-458.

Çoban-Yildiz, Y., Fabbri, D., Baravelli, V., Vassura, I., Yilmas, A., Tugrul, S., and Eker-Develi, E. (2006). Analytical pyrolysis of suspended particulate organic matter from the Black Sea water column. Deep Sea Res. Part II Top. Stud. Oceanogr. 53, 1856-1874.

Finster, K., Bak, F., and Pfennig, N. (1994). Desulfuromonas acetexigens sp. Nov., a dissimilatory sulfurreducing eubacterium from anoxic freshwater sediments. Arch. Microbiol. 161, 328-332.

Fuchsman, C. A., Kirkpatrick, J. B., Brazleton, W. J., Murray, J. W., and Staley, J. T. (2011). Metabolic strategies of free-living and aggregate associated bacterial communities inferred from biological and chemical profiles in the Black Sea suboxic zone. FEMS Microbiol. Ecol. 78, 586-603.

Fuchsman, C. A., Konovalov, S. K., and Murray, J. W. (2008). Concentration and natural stable isotope profiles of nitrogen species in the Black Sea. Mar. Chem. 111, 90-105.

Fuchsman, C. A., Staley, J. T., Oakley, B. B., Kirkpatrick, J. B., and Murray, J. W. (2012). Free-living and aggregate-associated Planctomycetes in the Black Sea. FEMS Microbiol. Ecol. 80, 402-418.

Gevertz, D., Telang, A. J., Voordouw, G., and Jenneman, G. E. (2000). Isolation and characterization of strains CVO and FWKO B, two novel nitrate-reducing, sulfide oxidizing bacteria isolated from oil field brine. Appl. Environ. Microbiol. 66, 2491-2501.

Glaubitz, S., Labrenz, M., Jost, G., and Jurgens, K. (2010). Diversity of active chemolithoautotrophic prokaryotes in the sulfidic zone of a Black Sea pelagic redoxcline as determined by rRNA-based stable isotope probing. FEMS Microbiol. Ecol. 74, 32-41.

Glaubitz, S., Lueders, T., Abraham, W. R., Jost, G., Jurgens, K., and Labrenz, M. (2009). C-13-isotope analyses reveal that chemolithotrophic Gamma- and Epsilonproteobacteria feed a microbial foodweb in a pelagic redoxcline of the central Baltic Sea. Environ. Microbiol. 11, 326-337.

Grunke, S., Felden, J., Lichtschlag, A., Girnth, A. C., De Beer, D., Wenzhofer, F., and Boetius, A. (2011). Niche differentiation among matforming, sulfide-oxidizing bacteria at cold seeps of the Nile Deep ea Fan (Eastern Mediterranean Sea). Geobiology 9, 330-348.

Hannig, M., Lavik, G., Kuypers, M. M. M., Woebken, D., Martens-Habbena,

B. Paul, S. Konovalov, A. Romanov, E. Yakushev, B. Tebo for nutrient, manganese, and oxygen data. We would like to thank Sergey Konovalov for help planning the autotrophic denitrification experiment, and Paul Quay for use of the mass spectrometer. Thank you to G. Rocap, W. Brazelton, and the reviewers for manuscript edits. Funding was provided by OCE 0081118, MCB0132101, OCE0649223. Clara A. Fuchsman was supported by an IGERT traineeship in Astrobiology under NSF grant 05-04219.

W., and Jurgens, K. (2007). Shift from denitrification to anammox after inflow events in the central Baltic Sea. Limnol. Oceanogr. 52, 1336-1345.

Hewson, I., and Fuhrman, J. A. (2006). Improved strategy for comparing microbial assemblage fingerprints. Microb. Ecol. 51, 147-153.

Heylen, K., Vanparys, B., Wittebolle, L., Verstraete, W., Boon, N., and De Vos, P. (2006). Cultivation of denitrifying bacteria: optimization of isolation conditions and diversity study. Appl. Environ. Microbiol. 72, 2637-2643.

Hoeft, S. E., Kulp, T. R., Stolz, J. F., Hollibaugh, J. T., and Oremland, R. S. (2004). Dissimilatory arsenate reduction with sulfide as an electron donor: experiments with Mono Lake water and isolation of strain MLMS-1, a chemoautotrophic arsenate respirer. Appl. Environ. Microbiol. 70, 2741-2747.

Huse, S. M., Dethlefsen, L., Huber, J. A., Welch, D. M., Relman, D. A., and Sogin, M. L. (2008). Exploring microbial diversity and taxonomy using SSU rRNA hypervariable tag sequencing. PLoS Genet. 4, el000255. doi:10.1371/journal.pgen.1000255

Ivanov, L. I., and Samodurov, A. S. (2001). The role off lateral fluxes in ventilation of the Black Sea. J. Mar. Syst. 31, 159-174.

Jensen, M. M., Kuypers, M. M. M., Lavik, G., and Thamdrup, B. (2008). Rates and regulation of anaerobic ammonium oxidation and denitrification in the Black Sea. Limnol. Oceanogr. 53, 25-36.

Jensen, M. M., Petersen, J., Dalsgaard, T., and Thamdrup, B. (2009). Pathways, rates and regulation of $\mathrm{N} 2$ production in the chemocline of an anoxic basin, Mariager Fjord, Denmark. Mar. Chem. 113, 102-113.

Kirkpatrick, J., Oakley, B., Fuchsman, C., Srinivasan, S., Staley, J. T., and Murray, J. W. (2006). Diversity and distribution of Planctomycetes and related bacteria in the suboxic zone of the Black Sea. Appl. Environ. Microbiol. 72, 3079-3083.
Konovalov, S. K., Fuchsman, C. A., Murray, J. W., and Belokopitov, V. N. (2008). Models of the distribution of nitrogen species and isotopes in the water column of the Black Sea. Mar Chem. 111, 105.

Konovalov, S. K., Luther, G. W. III, Friederich, G. E., Nuzzio, D. B., Tebo, B. M., Murray, J. W., Oguz, T., Glazer, B., Trouwborst, R. R., Clement, B., Murray, K. J., and Romanov, A. S. (2003). Lateral injection of oxygen with the Bosporus Plume-fingers of oxidizing potential in the Black Sea Limnol. Oceanogr. 48, 2369-2376.

Konovalov, S. K., and Murray, J. W. (2001). Variations in the chemistry of the Black Sea on time-scales of decades (1960-1995). J. Mar. Syst. 31, 217-243.

Kuypers, M. M. M., Sliekers, A. O., Lavik, G., Schmid, M., Jorgensen, B. B., Kuenen, J. G., Sinninghe Damste, J. S., Strous, M., and Jetten, M. S. M. (2003). Anaerobic ammonium oxidation by anammox bacteria in the Black Sea. Nature 422, 608-611.

Lam, P., Jensen, M. M., Lavik, G., McGinnis, D. F., Muller, B., Schubert, C. J., Amann, R., Thamdrup, B., and Kuypers, M. M. M. (2007). Linking crenarchaeal and bacterial nitrification to anammox in the Black Sea. Proc. Natl. Acad. Sci. U.S.A. 104, 7104-7109.

Lavik, G., Stuhrmann, T., Bruchert, V., Van der Plas, A., Mohrholz, V., Lam, P., Mussmann, M., Fuchs, B. M., Amann, R., Lass, U., and Kuypers, M. M. M. (2009). Detoxification of sulphidic African shelf waters by blooming chemolithotrophs. Nature 457, 581-585.

Luther, G. W. III, Church, T. M., and Powell, D. (1991). Sulfur speciation and sulfide oxidation in the water column of the Black Sea. Deep Sea Res. A 38, S1121-S1137.

Moussard, H., Corre, E., CambonBonavita, M., Fouquet, Y., and Jeanthon, C. (2006). Novel uncultured epsilonproteobacteria dominate a filamentous sulphur mat from the $13 \mathrm{~N}$ hydrothermal vent field, East Pacific Rise. FEMS Microbiol. Ecol. 58, 449-463. 
Murray, J. W., Codispoti, L. A., Friederich, G. E. (1995) "Oxidationreduction environments: the suboxic zone in the Black Sea" in Aquatic Chemistry: Interfacial and Interspecies Processes. Advances in Chemistry Series, Vol. 224, eds C. P. Huang, C. R. O'Melia, and J. J. Morgan (Washington DC: American Chemical Society), 157-176.

Murray, J. W., Top, Z., and Özsoy, E. (1991). Hydrographic properties and ventilation of the Black Sea. Deep Sea Res. A 38, S663-689.

Oguz, T., and Rozman, L. (1991). Characteristics of the Mediterranean underflow in the southwestern Black Sea continental shelf/slope region. Oceanol. Acta 14, 433-444.

Polz, M. F., and Cavanaugh, C. M. (1998). Bias in template-to-product ratios in multitemplate PCR. Appl. Environ. Microbiol. 64, 3724-3730.

Poulain, P., Barbanti, R., Motyzhev, S., and Zatsepin, A. (2005). Statistical description of the Black Sea nearsurface circulation using drifters in 1999-2003. Deep Sea Res. Part I Oceanogr. Res. Pap. 52, 2250-2274.

Rainey, F. A., Ward, N., Sly, L. I., and Stackebrandt, E. (1994). Dependence on the taxon composition of clone libraries for PCR amplified, naturally occurring $16 \mathrm{~S}$ rDNA, on the primer pair and the cloning system used. Experientia 50, 796-797.

Shao, M., Zhang, T., and Fang, H. H. P. (2009). Autotrophic denitrification and its effect on metal speciation during marine sediment remediation. Water Res. 43, 2961-2968.

Sievert, S. M., Scott, K. A., Klotz, M. G., Chain, P. S. G., Hauser, L. J., Hemp, J., Hugler, M., Land, M., Lapidus, A., Larimer, F. W., Lucas, S., Malfatti, S. A., Meyer, F., Paulsen, I. T., Ren, Q., and Simon, J. (2008). Genome of Epsilonproteobacterial chemolithoautotroph Sulfurimonas denitrificans. Appl. Environ. Microbiol. 74, 1145-1156.

Sievert, S. M., Wierings, E. B. A., Wirsen, C. O., and Taylor, C. D. (2007). Growth and mechanism of filamentous-sulfur formation by Candidatus Arcobacter sulfidicus in opposing oxygen-sulfide gradients. Environ. Microbiol. 9, 271-276.

Steele, J. A., Countway, P. D., Xia, L., Vigis, P. D., Beman, J. M., Kim, D. Y., Chow, C. T., Sachdeva, R., Jones, A. C., Schwalbach, M. S., Rose, J. M., Hewson, I., Patel, A., Sun, F., Caron, D. A., and Fuhrman, J. A. (2011). Marine bacterial, archaeal and protistan association networks reveal ecological linkages. ISME J. 5, 1414-1425.

Stewart, F. J., Ulloa, O., and DeLong, E. F. (2012). Microbial metatranscriptomics in a permanent marine oxygen minimum zone. Environ. Microbiol. 14, 23-40.

Takai, K., Suzuki, M., Nakagawa, S., Miyazaki, M., Suzuki, Y., Inagaki, F., and Horikoshi, K. (2006). Sulfurimonas paralvinellae sp nov., a novel mesophilic, hydrogen- and sulfuroxidizing chemolithoautotroph within the Epsilonproteobacteria isolated from a deep-sea hydrothermal vent polychaete nest, reclassification of Thiomicrospira denitrificans as Sulfurimonas denitrificans comb, nov and emended description of the genus Sulfurimonas. Int. J. Syst. Evol. Microbiol. 56, 1725-1733.

Tarpgaard, I. H., Boetius, A., and Finster, K. (2006). Desulfobacter psychrotolerans sp. nov., a new psychrotolerant sulfate-reducing bacterium and descriptions of its physiological response to temperature changes. Antonie Van Leeuwenhoek 89, 109-124.

Taylor, C. D., and Wirsen, C. O. (1997). Microbiology and ecology of filamentous sulfur formation. Science 277, 1483-1485.

Thamdrup, B., Rossello-Mora, R., and Amann, R. (2000). Microbial manganese and sulfate reduction in Black Sea shelf sediments. Appl. Environ. Microbiol. 66, 2888-2897.

Trowborst, R. E., Clement, B. G., Tebo, B. M., Glazer, B. T., and Luther, G. W. III. (2006). Soluble Mn(III) in suboxic zones. Science 313, 1955-1957.

van de Vossenberg, J., Rattray, J. E. Geerts, W., Kartal, B., van Niftrik, L., van Donselaar, E. G., Sinninghe Damste, J. S., Strous, M., and Jetten, M. S. M. (2008). Enrichment and characterization of marine anammox bacteria associated with global nitrogen gas production. Environ. Microbiol. 10, 3120-3129.

Vandieken, V., Mussmann, M., Niemann, H., and Jorgensen, B. B. (2006). Desulfuromonas svalbardensis sp. Nov. and Desulfuromonas ferrireducens sp. Nov., psychrophilic, $\mathrm{Fe}(\mathrm{III})$ reducing bacteria isolated from Arctic sediments, Svalbard. Int. Syst. Evol. Microbiol. 56, 1133-1139. Vandieken, V., Pester, M., Finke, N., Hyun, J., Friedrich, M. W., Loy, A., and Thamdrup, B. (2012). Three manganese oxide-rich marine sediments harbor similar acetateoxidizing manganese-reducing bacteria. ISME J. doi:10.1038/ ismej.2012.41

Vetriani, C., Tran, H. V., and Kerkhof, L. J. (2003). Fingerprinting microbial assemblages from the oxic/anoxic chemocline of the Black Sea. Appl. Environ. Microbiol. 69, 6481-6488.

Walsh, D. A., Zaikova, E., Howes, C. G., Song, Y. C., Wright, J. J., Tringe, S. G., Tortell, P. D., and Hallam, S. J. (2009). Metagenome of a versatile chemolithoautotroph from expanding oceanic dead zones. Science 326, 578-582.

Wang, J., Jenkins, C., Webb, R. I., and Fuerst, J. A. (2002). Isolation of Gemmata-like and Isophaeralike bacteria from soil and freshwater. Appl. Environ. Microbiol. 68, 417-422.

Wirsen, C. O., Sievert, S. M., Cavanaugh, C. M., Molyneaux, S. J., Ahman, A., Taylor, L. T., DeLong, E. F., and Taylor, C. D. (2002). Characterization of an autotrophic sulfide-oxidizing marine Arcobacter sp. that produces filamentous sulfur. Appl. Environ. Microbiol. 68, 316-325.

Zhang, M., Zhang, T., Shao, M. F., and Fang, H. H. P. (2009). Autotrophic denitrification in nitrate-induced marine sediments remediation and Sulfurimonas denitrificans like bacteria. Chemosphere 76, 677-682.

Zumft, W. G. (1997). Cell biology and molecular basis of denitrification. Microbiol. Mol. Biol. Rev. 61, 533.

Conflict of Interest Statement: The authors declare that the research was conducted in the absence of any commercial or financial relationships that could be construed as a potential conflict of interest.

Received: 20 January 2012; accepted: 30 June 2012; published online: 18 July 2012. Citation: Fuchsman CA, Murray JW and Staley JT (2012) Stimulation of autotrophic denitrification by intrusions of the Bosporus Plume into the anoxic Black Sea. Front. Microbio. 3:257. doi: 10.3389/fmicb.2012.00257

This article was submitted to Frontiers in Aquatic Microbiology, a specialty of Frontiers in Microbiology.

Copyright (c) 2012 Fuchsman, Murray and Staley. This is an open-access article distributed under the terms of the Creative Commons Attribution License, which permits use, distribution and reproduction in other forums, provided the original authors and source are credited and subject to any copyright notices concerning any third-party graphics etc. 


\section{APPENDIX}

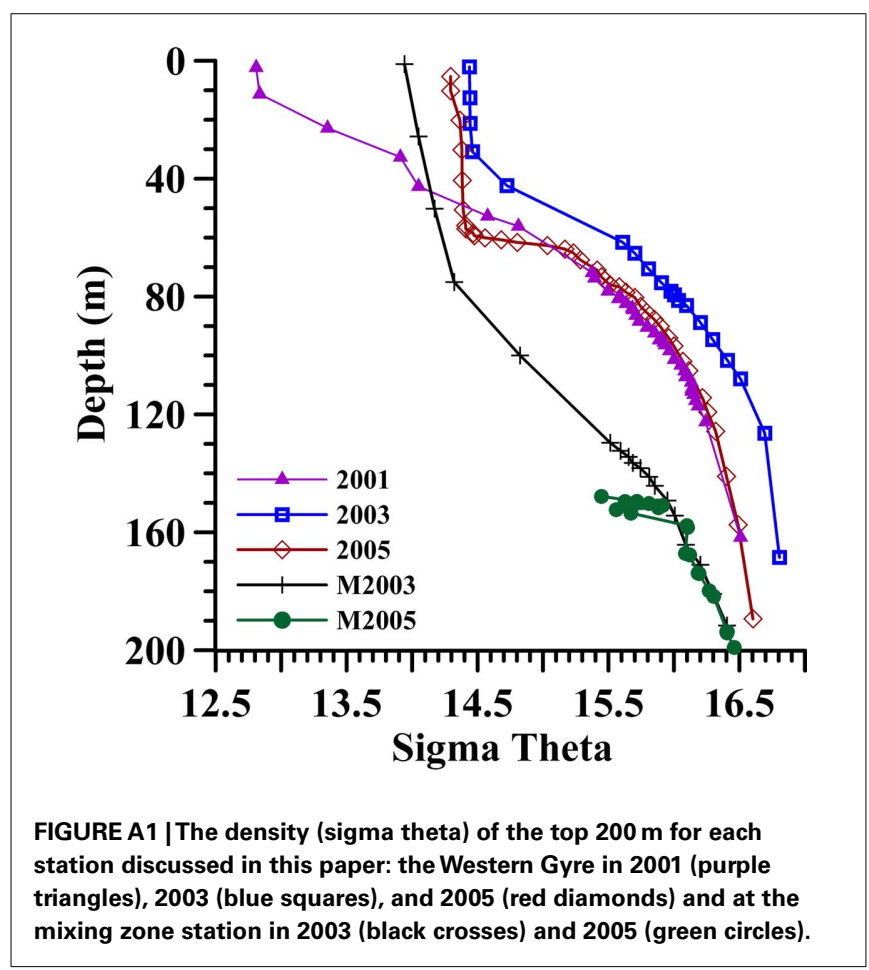

